Thermal and meahantad entheve of shape momory alloxs H. Sade ${ }^{1}$. E. Hornbogen, Inst1tut fur Werkstofle, Ruhr Universitat Bochum, ERG.

\title{
Intreoducteon
}

Dlfferent rodes of fatloue can bo induced in shape merory alloys. Thermal latlgue is delined as due to cyclic temperaturo changes in the rango for whlch austenlte $(\beta)$ 1s atable: Trax, 1 , down to temperatures at which tho transformation is comploto Tmin $M$. Several modes of mechantcal fatigue aro possible. They includo latigue of stable austenlte (T>AP), of stable martensite (T<HP). during psoudoelastic cycles (Md) $T$. Md = highest temperature to whlch martenslte can be stress induced). Bach of the mentioned modes provides different microplast1c1ty mechanisms (1). Several intermedlate thermomechanlcal fat1gue treatment are also possiblo. An exarplo is the thermal cycling through the martensitio transforination. under a simultaneous application of load.

Fatlgue of single and polycrystalline $\mathrm{Cu}$ base shape memory alloys has been studied and the results can be found in the 11 terature $(2,12)$. In the studies on fatigue in single crgstals of Cu based allops tho dependence of the number of cycles to fracture on several parameters, 1.e. applied stress, axis orlentation, test terperature, etc. $(3,4,5,9,10)$ and their relationship to structural changes havo been analysed (13). It has been shown that due to pseudoelastic cycling of Cu-Zn-Al alloys the density of dislocations which form crystallographlc arrangemonts increases in the intorlor, that martensite is retalned, and that at the surface slip steps. Intrusions, extrusions and microcracks develop.

Most of the works however, have been performed in polycrystals $(6,7,8)$. Grain boundarles in bcc long rango ordered shape memory alloys provide sites of sovoro Incompatiblilty becauso of the high olastic anlsotropy. They are often extremoly brittlo, for example In the Intermetallic compound n-Cuzn (14). Fatigue of polycrystals of shape wewory alloys has predominantly shown the presence of intercrystalline fracture. For fatioue crack growth grain boundaries can be sites for lmpedement or provide an easy Intercrystallines path $(15,16)$.

It is the purpose of this paper to surmarlze some results obtalned with sinele crystals, and discuss thelr relevance for polycrystalline materials. In this paper emphasis w11l be put on the relationship between the different modes of latigue in the shape mewory alloys. It will be discussed to what extent single crystal studies can alve information also on the behavior of polycrystals, and on what factors thls depends. For this reason the experimental procedures and results of existing data will bo summarized and some new Information wlll be presented, all for

Humboldt-Follow, on leave from Contro Atomlco Bariloche, Argentina 
$\mathrm{Cu}-\mathrm{Zn}$ and $\mathrm{Cu}-\mathrm{Zn}-\mathrm{Al}$ alloys. Hero $\beta$ will bo used to deslenate the austenite and $M$ do martensite, Indistinctly for CuZn and CuZnAl alloys. M represents the $8 R$ structure in $\mathrm{Cu}-\mathrm{Zn}$ alloys and $18 \mathrm{R}$ in Cu-Zn-Al alloys.

\section{Bxperimental precedure}

The experimental procedure has been explained in previous reports $(1,3)$. Only a short sumbary 18 glven horo. Tho singlo crystals were erown by the Bridgman technlque. Samples were annealed for 2 hours at $800 \mathrm{C}$ and then alr cooled. Thelr surfaces were mechanlcally (600 grade paper) and electrolytically pollshod. Hochanlcal cycling was performed in closed loops at different test tomperatures above Ms. The maximum deformation was kept constant during the cycling of the single crystal specimens. Light and olectron olcroscopy (SBM and TBM) were used to study the delect structures after cycling. Thermal cycling under load was performed in a specially deslened temperature chamber (17). A $\mathrm{Cu}-2 n-A 1$ alloy of $\mathrm{Ms}^{2}=10^{\circ} \mathrm{C}(\mathrm{Cu}-24.26$ at $\times 2 n-3.32$ at $\times$ Al) was chosen for experiments with polycrystallino specimens. The samples vere annealed at $800 \mathrm{C}$ for 2 hours and water quenched.

\section{Experimental results}

Elcure la shows stress strain curves for a polycrystaline sample after several pseudoelastic cycles, for a maximum stress of 75 HPa. The maximum stress was kept constant durine cycline. A strong change in the slope of the stress-strain curve can be noted, which loplies that a constant maximum deformation during cycling (as used in single crystals) would load after a low number of cycles to hich stresses and fracture. However the experimental conditions were controlled in order to allow a waximum plastlc deformation of approximately 1x. A hicher amount of plastlc deformation led to intercrystaline fracture at a low number of cycles. A softening assoclated with the start of the transformation and a hardening durine the progression of the transformation is observed. Consequences of this cycline on the temperature of transfornation can be found in Ref. (18). The evolution of stress strain curves during psoudoelastic cyclins under tensilo load for a single crystal is presented in $11 \mathrm{~g}$. $1 \mathrm{~b}$. An increase in the hysteresis, a swoother onset of the $B-B$ transformation and hardenine durine the transformation are present aftor cycling.

The wost detalled results have been obtalned for a single crystal of a Cu-15.14atx2n-16.43at. XAl alloy, of Hs -5 . samples of which were pseudoelastlcally cycled at constant temperature. F1gure 2 shows one of the samples under tenslle stress and a deformation corrrespondine to $50 x$ of the pseudoelastic transformation (2a: before cycling, $b, c$ and $d$ : after pseudoelastlc cycling). The boundary between martensitlc bands and the austenito is clearly seen. Transmission electron microscopy studies as well as the evolution of stress-strain curves have been analysed previously $(13,3)$. Dislocations form in the interlor crystallographic arrancewents which are elongated in the intersection between the martensitlc hablt plane and the basal plane of the martensite. 

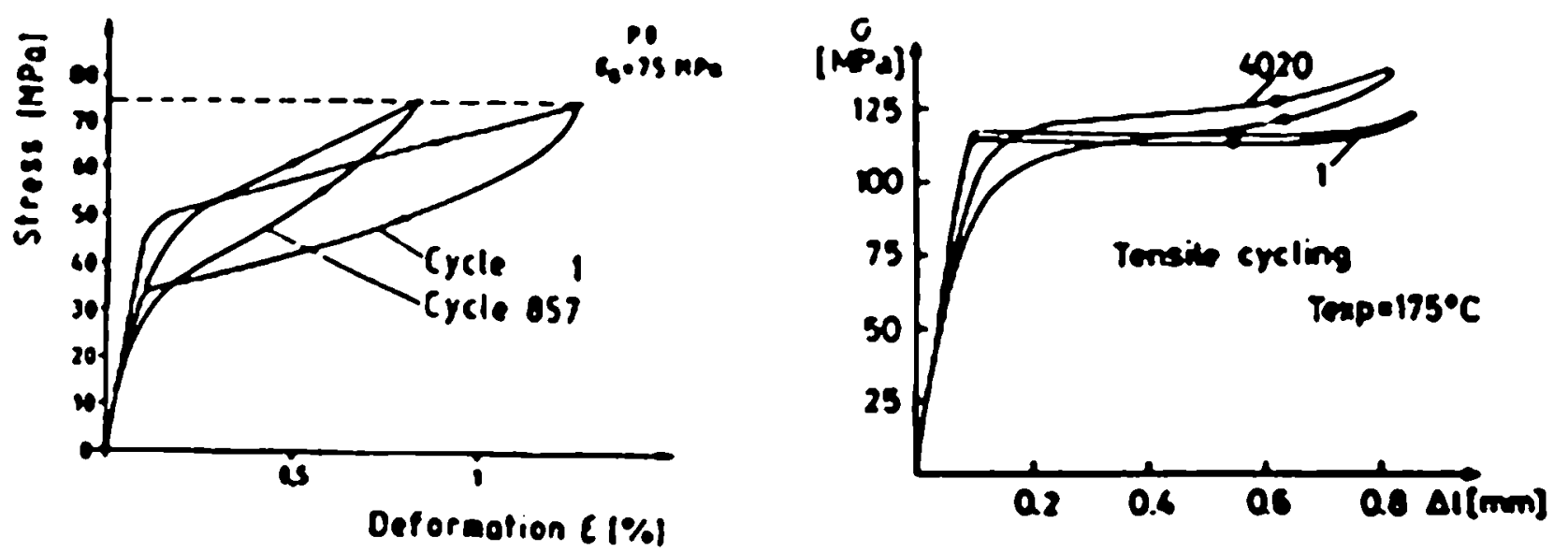

B18. 1: Change in the course of o-c curves with the number of pseudoolastlo cycles. a) polycrystalline samplo, maximum stress $=76 \mathrm{MPa}$, b) singlo crystal spoclmen. Hs $=-20$.
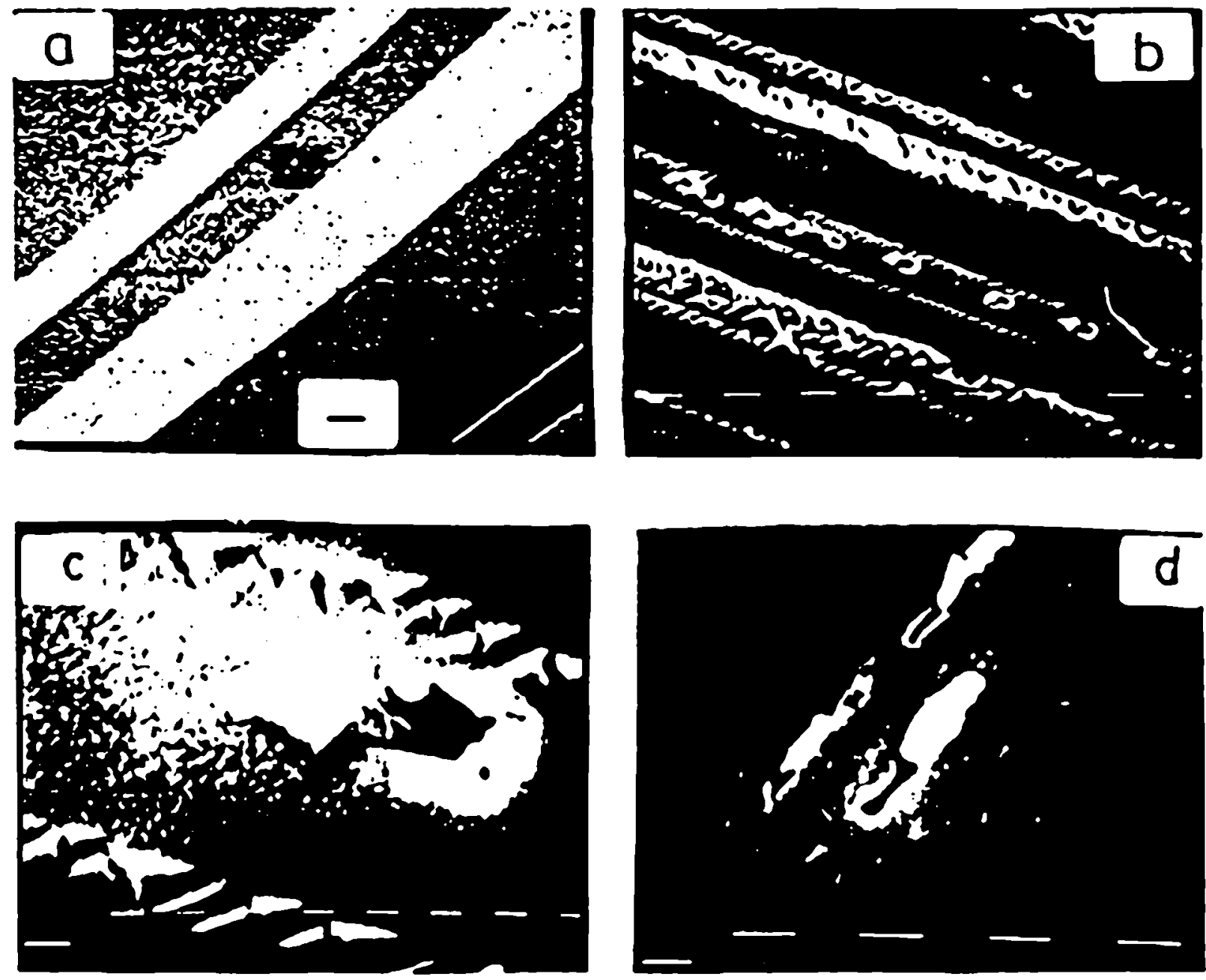

P18.2: 6.B.H. analysis of surface defocts after psoudoolast1c crcilne of singlo crystalo (a,b,c in sltu observation under load). Bar Indlcatos $1 \mu \mathrm{m}\left(T\right.$ exp $=20^{\circ}$ ). a) partlally transformed state, plrot oycle. b,c) Partially transformed condition after 3000 cycles. d) surface morpbology after 3000 crcles as observed in tho stress free condition. 
Tho Interaction of these defects with the surface give orleln to ollp steps. Alter additional cycling the steps grow in the surface and dovelop lirst extrusions-intrusions and linally micro-cracks whlch brow into the interlor of the specimens. Characteristic is a banded structure whlch contalns holes with tongue shaped extrusions (118.2d). Wleht and scanning electron mlcroscopy of the surface of polycrystallino samples have made v1sible defects of the sams type of extrusions-intrusions as shown In 118.2 for single crystals. An examplo is presented in 118.3 . thoso dofects aro allened parallel to tho $(110)$ p planes which are parallel to the hablt plano of the martenslte. These hablt plane defects are simllar to those in single crystals and are thought to be responsible for the nucleation of microcracks whlch lead to Practure in single crystals, both in tension (3) and in compression (19). These experlments aro an example of the close olmlarity with single crystalline surface defects provided. as wlll be shown. If strain Inoompatiblilties at grain boundarles are kopt low enough. Samples of the same alloy which were thermally crcled under load lractured at grain boundarles (18). However. when compared both kind of experiments 1 t should be kept in alnd that deformation is a free varlable when the specimen transforms under constant load. and it reaches values higher than $5 x$. The amount of deformation is related to the stress concentration at eraln boundarles.

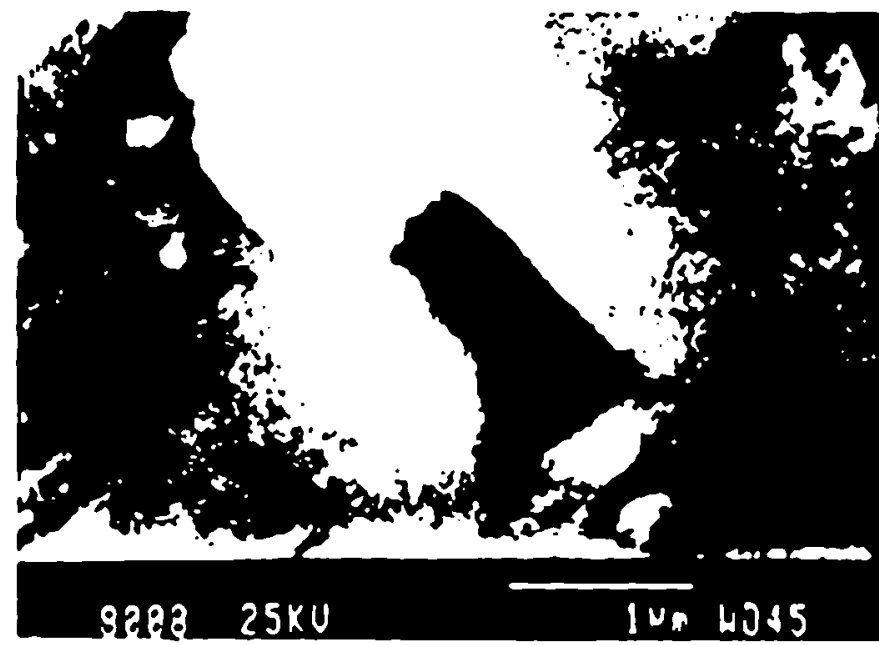

F18.3: Intrusion-extrusion at the surface of a polycrystallino spocimen, after 758 pseudoolastlc cycles. $\quad 0 \quad \max =25 \mathrm{MPa}$. $c \max =0.8 x$. Texp $=20^{\circ}$.

Strain compatiblilty problews at graln boundarles aro tho ner feature if polycrystals are treated. Tholr consequences on fatlgue crack erowth and speclwen life have been reported (1). It has been found that a largo number of shoar systems is Induced near grain boundarles, and that intercrystalline eracturo occurs assoclated with transcrystalline deformation, being the more pronounced tho hlcher tho test temperature is above Ms. It Indlcates that true plastlc doformation and not transformation by self-accommodating groups is lavouring graln boundary cracking. 
There are at least two addltional mechanlsms which can favour transcrystalline deformation compared to Intercrystalline fracture In polycrystals (1.17): a) Under cyclic loading in the martensitic state (1.e. T \& HI), nucleation of cracks at varlous boundarles between martensite varlants is favoured. Crack inltiation has been found at varlant boundarles with orlentations normal to tho external load after mochanlcal cycling at constant terperature $T<M e$ for an alloy of $\mathrm{Hs}=120^{\circ} \mathrm{C}(\mathrm{Cu}-24.08 \mathrm{atxZn-8.102at \times Al)}$. Crack initlation at varlant boundarlos was also found 12 tho thermal cycling throush the transformation preceeded tho mechanlcal cycling. An examplo has been presented for an $\mathrm{Cu}-38.84 \mathrm{atx} \mathrm{n}$ alloy ( $\mathrm{Hs}=-7^{\circ} \mathrm{C}$ ), whlch was wechanlcally cycled apter 30 therwal cycles. It 13 not clear t1ll now 18 microcracks that appear at varlant boundalres are lormed by the same wechanism which controls the nucleation of the hablt plane defects in single crystal spoolmens.

b) A socond way to avold grain boundary Induced latiguo cracking is a chanco in erain boundary morphology. After botatizing a Cu-zn-Al polycrystal by heating onco more to the betatizing temperature at which it $1 \mathrm{~s}$ rolled, and by subsequently pater quenching produces boundarles wlth rueged wlcrostructure as shown in I18. 4. This alfects the forwation of dislocations and segregation in 1 ts environment in such a way that no grain boundary cracking is observed. It has been shown that both mechanisms a and $b$, Inoroaso specimen 11 lo by about the samo amount, but less than ono order of magnitude.

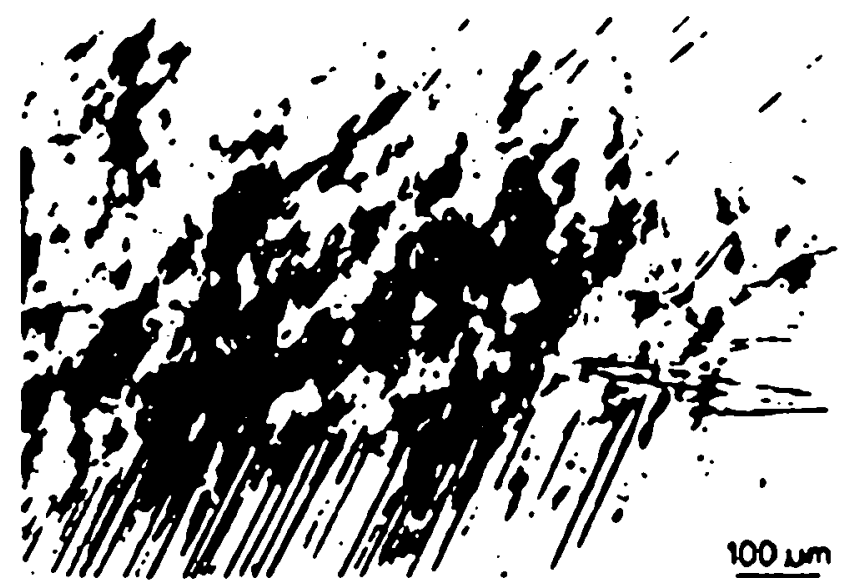

F1g.4: H1ghly doformod B-boundary. S11p steps do not Interact with grain boundarles. Fracture is now Intracrystalline (17)

\section{Dlscusseon}

The essence of the experimental results is that the behavior of single crystals 13 similar to the behavior of polycrystalline material if intercrystalino embrittloment is removed. Th1s is possible 18 the alloys remain in the martensitic state or 12 the amount of deformation is sufflclently small and allows single crystal defects to nucleato before hlgh stress 
concentration in grain bouridarles accumulate. Therefore, studies of single crystal are worthwhlle for the fundarental understariding of latigue wechanisms and fatlgue life of shape wemory alloys.

Special attention has been paid to the formation of surface defects, bainly to intrusions-extrusions during pseudoelastic cycling. These hablt plane defects are considered to be the orlgin of microcracks both in pseudoelastic cycling under tension and under compression stress, in single crystals. Bxperiments porformed with polycrystalline specimens have shown the same typo of surface defocts if the deformation $1 \mathrm{~s}$ kopt low enough. Tho Iinfluence of this inlcrocrack formation has been mostly overlooked in experiments which were performed with polycrystalilno specimens. The reason is that crack nucleation and fracture at s-grain boundaries has been the normal mechanisw conducting to crack nucleation and fracture in Cu based alloys.

The following path can be suggested for the formation of these hablt plane defects due to pseudoelastic cycling, if the dislocation structure and surface phenomena are considered:

1. Stress induced formation of a martensite crystal of wideh which corresponds to the length of the hole whlch 13 observed in a later stage.

2. Plastic deformation in the interface and on the slip systems in the interior of this martensite crystal. It should bo mentioned here that dislocations found in the $\beta$ phase after pseudoelastic cyoling lie in the hablt plane of the transformation and in the plane whlch transforms to the basal plane of the martensite (13).

3. During the $M-\beta$ reversion the intra-martensitic plastic deformation is pulled back. Simliar to external tension-coppression cycling in classical latloue this reversion of plastic deformation is not quite complete.

4. The variant Interface linits sldeways erowth of the slip step during subsequent cyclic tension or compression. Repeated reversion of intramartensitic plastic doformartion produces lito tongue-like extrusion and rectangular hole as a consequence ol limlted cross-s11p and therefore incomplete plastio reversibility. A support for the suggested mechanism is found in f18.5.A SEM ploturo shows o singlo crystal under tensilo load. The dark bands are stress induced martensite and the hell ones are $B$. The intruslons-extrustons 110 on the rartensitic bands and they are $11 m 1$ ted by the $\beta-M$ boundary.

It should be noted that surface treatwents applied to singlo crystals specimens have shown that a considerable increase in fatigue life can be obtained if intrusion-extrusion type defects are ellwinsted at intermitent stages of cycling (3). On the other hand, erain boundary brlttleness can be removed after an adequate thermomechanlcal troatment. leading also to an Increase in fatigue 11fe. To which extent. this and other posglble treatments can be comblned and applied to polycrystalline mater1al. w11l depend on the type of fatiglie involved. As an example removal of hablt plane defects and modlfication of grain boundary morphology should be required in the psoudoelastic teroperture range. 
If thormally inducod martons 1 to 18 mochanlcally latigued, tho rolo of B-erain boundorios is smaller duo to tho martionatto varlant

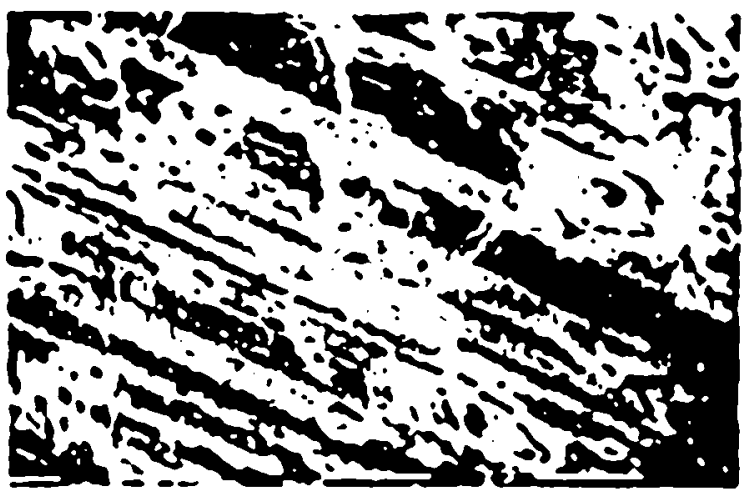

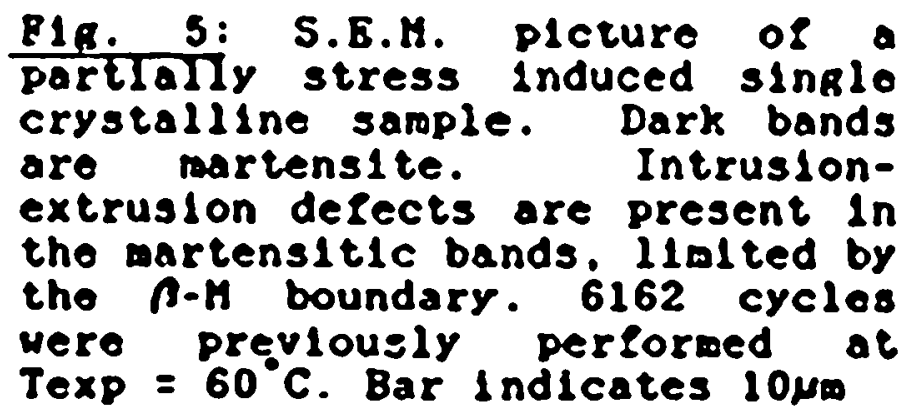

boundarles, whlch act as new sltes for cleavaso. Intramartensltic deformation 15 also present in this caso (7). Deformation mochanloms found in olnglo oxygtals should play a dominant rolo horo. Intramartensitio deformation can bo related to defects lylng in basal planes of wartenslte, which wero lound in singlo crystal due to pseudoelastic cycling (3). However these "basal plane defects" played a minor role in wicrocrach nucleation. which was wostly connected with bablt plane defects.

\section{Summacy}

Consoquences of latleue on single and rolycrystalline spoclmons have been analysed. Defects whlch oppear on the surface, whlch lead to microcrack nucleation, have been used in this analysis. However this can be extended to the evolution of the interlor of tho specloens and lis relation to changes in stress deformation curves. Further research is made in thls dlroction.

\section{dcknoriledremente}

The authors want to ithank the slexander von Humboldt-Foundation who provided for the research work of Dr. H. Sade. Dr. M. Thumann has contributed valuable discussions concerning latlaue in polycrystals. Sow of the results from hls Dr. -Ing. thesls (Bochum 1986, see rel.17) were used in this paper. $M$. Sade thanks Dr. H. Ahlers for valuable discusslons.

\section{Bererences}

(1) M. Thumann, B. Hornbogen: 2. Metallkdo. 78 (1988) 119.

(2) H. Sakamoto, K. Shimizu: Transactions JIM. $27 N^{8}$ (1986) 601.

(3) M. Sade. R. Rapac1011. H. Ablers: Acta Hot. 33 (1885) 487. 
(4) L.C. Brown: Het. Trans. A, 10A (1878) 217.

(5) L.C. Broun: Het. Trans. A.. $12 A$ (1881) 353.

(6) Jell Perkins, R.0. Sponholz: Met. Trans. A.. $15 A$ (1984) 313.

(7) J. Janssen, F. HIllogs, B. Verolot, J. Maertens, L. Delaer: J. do Physique, C4, N 12, Tome 43 (1882) 808.

(8) R. Oshima and N. Yoshida: J. de Physlque, C4, $N^{\bullet} 12$, Tome 43 (1882) 803 .

(8) M. Sado and H. Ahlers: Scrlpta Mot. 18 (1985) 425.

(10) L. Delaey, J. Janssen, D. Van do Mosselaer, O. Dullenkopl, A. Deruyttere: Scrlpta Met., 12 (1878) 373.

(11) H. Andrade, J. Jansson, L. Delaey: Motallocraphy 18 (1985) 107.

(12) K.N. Molton, O. Horcler: Scripta Hot. 13 (1879) 73.

(13) H. Sade, A. Uribarr1. R. Loveg: Ph11. Hag. A SS (1887) 445.

(14) V. Verlinden, L. Dolaey: Het. Trans.. 18A (1888) 207.

(15) K.11. Zum Gahr, B. Hornbogen: Acta Mot 24 (1976) 581.

(16) M. Grxe, B. Hornbosen: Acta Mot. 25 (1877) 877.

(17) M. Thumann: Mechanlsche un thermlsche Broudune in $B-C u-2 n-X$ Formgedychtnisleglerungen, VDI Portschrlttsberlchto Relhe 5x, DUssoldor 1987.

(18) H. Sade, Jorg Kumplert, B. Hornbocen: 2 . Hetallkde. 79, H. 10 (1988) 678.

(19) M. Sade, B. Lovey, M. Ahlers: Proc. of ICOMAT (1886) 934. 